\title{
PERBANDINGAN PELAKSANAAN STRATEGI PEMBELAJARAN PQ4R DAN PETA KONSEP DALAM UPAYA MENINGKATKAN KINERJA GURU DAN AKTIVITAS SISWA KELAS XI SMA DI BANJARMASIN
}

\author{
Siti Ramdiah \\ STKIP-PGRI Banjarmasin \\ E-mail: sitiramdiah@gmail.com
}

\begin{abstract}
ABSTRAK
Strategi pembelajaran sebagai bagian penting yang perlu diperhatikan untuk merancang proses pembelajaran belum secara maksimal dikembangkan oleh guru dalam meningkatkan kinerjanya dan keaktifan siswa dalam pembelajaran biologi. Strategi pembelajaran PQ4R dan peta konsep merupakan strategi pembelajaran yang memiliki karakteristik yang berbeda, namun diyakini mampu meningkatkan kinerja guru dan aktivitas siswa selama proses pembelajaran. Tujuan penelitian ini yaitu mendeskripsikan perbandingan strategi pembelajaran PQ4R dan peta konsep sebagai upaya peningkatan kinerja guru dan siswa SMA di Kota Banjarmasin. Penelitian ini menggunakan metode deskriptif berdasarkan hasil pengamatan selama proses pembelajaran dengan menggunakan strategi $P Q 4 R$ dan peta konsep pada kelas yang berbeda. Pengukuran keterlaksanaan penerapan strategi pembelajaran yang dilakukan dengan lembar pengamatan terhadap kinerja guru dan siswa yang disesuaikan dengan tahapan strategi pembelajaran $P Q 4 R$ dan peta konsep. Selanjutnya, siswa yang terlibat dalam penelitian yaitu siswa kelas XI IPA 1 dan 2 SMAN 10 Banjarmasin yang mengalami proses pembelajaran dengan strategi peta konsep. Sedangkan, siswa kelas XI IPA 2 SMA PGRI 4 dan SMA PGRI 7 Banjarmasin mengalami proses pembelajaran dengan strategi pembelajaran PQ4R. Hasil penelitian menunjukkan bahwa kedua strategi pembelajaran ini memiliki potensi yang sama untuk meningkatkan kinerja guru dan aktivitas siswa selama proses pembelajaran Biologi siswa kelas XI IPA SMA di Banjarmasin.
\end{abstract}

Kata Kunci: $P Q 4 R$, peta konsep, kinerja guru, aktivitas siswa

\section{PENDAHULUAN}

Pendidikan merupakan proses pemberdayaan berbagai keterampilan hidup yang harus diberikan kepada siswa. Pendidikan bagian penting yang membangun pengalamanpengalaman belajar bagi siswa selama proses pembelajaran. Selanjutnya, jika dipahami lebih mendalam ternyata pengalaman tersebut tidak hanya bagi siswa namun juga memberikan arti yang sangat besar bagi guru sebagai fasilitator selama pembelajaran. Ditambahkan oleh Suyono \& Hariyanto (2012) pembelajaran yang efektif bagi siswa berdasarkan sejumlah hasil riset kependidikan diperoleh melalui learning by teaching yang berarti bahwa pengajaran oleh guru ada pembelajaran pada siswa. Pada pembelajaran siswa ada pengajaran baik kepada sesama siswa atau dalam hal-hal tertentu dari siswa terhadap guru. Berbagai strategi pembelajaran yang telah digunakan merupakan kondisi nyata hasil belajar dan pembelajaran bagi guru dan siswa.

Sagala (2012) menjelaskan bahwa pendidikan adalah proses dalam rangka mempengaruhi siswa supaya mampu menyesuaikan diri sebaik mungkin dengan lingkungannya, menimbulkan perubahan pada dirinya sesuai dengan kompetensi yang telah dimiliki dalam kehidupan bermasyarakat. Hal tersebut sebagai usaha sadar yang salah satunya dilaksanakan dalam proses pembelajaran, dimana ada guru yang melayani siswa, melalukan penilaian keberhasilan belajar siswa.

Berdasarkan hal tersebut guru harus mampu melakukan proses pembelajaran yang memberikan pengalaman belajar yang bermakna bagi siswa. Berbagai strategi pembelajaran yang dapat dikembangkan dalam upaya peningkatan kinerja guru dan pemahaman konsep bagi siswa.Namun fakta di lapangan proses pembelajaran teacher centered masih banyak dilaksanakan. Siswa masih pasif dalam proses pembelajaran dan hanya menerima apa yang disampaikan oleh guru melalui metode ceramah. Hal ini berdampak kepada kompetensi yang dimiliki siswa seperti ketuntasan belajar yang masih sebagian besar belum tuntas. 


\section{JEMS (Jurnal Edukasi Matematika dan Sains)}

Tersedia online di: http://e-journal.ikippgrimadiun.ac.id/index.php/JEMS

Volume 4, Nomor 2, September 2016, hal 129-132

Proses pembelajaran yang membangun pengalaman belajar bermakna bagi siswa dapat dilakukan oleh guru dengan membuat rancangan yang berpotensi untuk meningkatkan kinerja guru dan aktivitas siswa. Rancangan tersebut memiliki strategi pembelajaran yang mengaktifkan siswa selama proses pembelajaran. Siswa melalui bimbingan guru melaksanakan tahapan demi tahapan dari strategi yang telah dirancang tersebut. Dengan demikian siswa akan mempu menemukan sendiri konsep, memahami secara mendalam materi, dan mampu mengkomunikasikan hasil temuan dengan baik selama proses pembelajaran.

Terkait dengan strategi pembelajaran tersebut, PQ4R maupun peta konsep memiliki karakteristik yang berbeda, namun berpotensi dalam mengaktifkan siswa selama proses pembelajaran. Kedua strategi ini membangun keterampilan berpikir siswa berdasarkan tahapan-tahapan yang harus dilakukan oleh siswa. Keterlaksanaan tahapan-tahapan tersebut dapat juga menilai kinerja guru selama proses strategi pembelajaran tersebut digunakan. Penelitian ini memiliki tujuan mendeskripsikan perbandingan strategi pembelajaran PQ4R dan peta konsep sebagai upaya peningkatan kinerja guru dan siswa SMA di Kota Banjarmasin.

\section{METODE PENELITIAN}

Metode penelitian yang diterapkan yaitu metode deskriptif berdasarkan hasil pengamatan selama proses pembelajaran dengan menggunakan strategi PQ4R dan peta konsep pada kelas yang berbeda. Pengukuran keterlaksanaan penerapan strategi pembelajaran yang dilakukan dengan lembar pengamatan terhadap kinerja guru dan siswa yang disesuaikan dengan tahapan strategi pembelajaran $\mathrm{PQ} 4 \mathrm{R}$ dan peta konsep. Pada lembar pengamatan aktivitas guru strategi pembelajaran PQ4R terdiri atas 16 komponen, untuk aktivitas siswa ada 17 komponen. Pada strategi pembelajaran peta konsep baik pada aktivitas guru maupun siswa yang diamati terdiri atas 15 komponen. Pengamatan dilakukan selama satu semester genap dengan cakupan materi meliputi Standar Kompetensi: 1) Memahami struktur dan fungsi sel sebagai unit terkecil kehidupan, 2) Memahami keterkaitan antara struktur dan fungsi jaringan tumbuhan dan hewan, serta penerapannya dalam konteks salingtemas, 3) Menjelaskan struktur dan fungsi organ manusia dan hewan tertentu, kelainan/penyakit yang mungkin terjadi serta implikasinya pada salingtemas. Guru model yang terlibat dalam penelitian ini sebelumnya telah mendapat materi sosialisasi terkait dengan strategi pembelajaran yang digunakan. Selanjutnya, siswa yang terlibat dalam penelitian yaitu siswa kelas XI IPA 1 dan 2 SMAN 10 Banjarmasin yang mengalami proses pembelajaran dengan strategi peta konsep. Sedangkan, siswa kelas XI IPA 2 SMA PGRI 4 dan SMA PGRI 7 Banjarmasin mengalami proses pembelajaran dengan strategi pembelajaran PQ4R.

\section{HASIL PENELITIAN DAN PEMBAHASAN}

Berdasarkan hasil pengamatan yang telah dilakukan pada saat proses pengamatan dan hasil analisis deskriptif. Selanjutnya data yang diperoleh dipersentasikan dan dibandingkan antara kedua strategi pembelajaran yang telah digunakan. Rerata keterlaksanaan tahapan masing-masing strategi pembelajaran yang digunakan akan dideskripsikan secara singkat sebagai berikut. Pada strategi pembelajaran PQ4R rerata komponen aktivitas guru adalah $96,88 \%$ dan rerata keterlaksanaan aktivitas siswa yaitu 96,81\%. Selanjutnya, pada strategi pembelajaran peta konsep rerata komponen aktivitas guru adalah $98,61 \%$ dan rerata keterlaksanaan aktivitas siswa yaitu 96,38\%. Grafik perbandingan kinerja guru dan aktivitas siswa selama proses pembelajaran dengan strategi PQ4R dan peta konsep dapat dilihat pada Gambar 1 dan 2. 
JEMS (Jurnal Edukasi Matematika dan Sains)

Tersedia online di: http://e-journal.ikippgrimadiun.ac.id/index.php/JEMS

Volume 4, Nomor 2, September 2016, hal 129-132

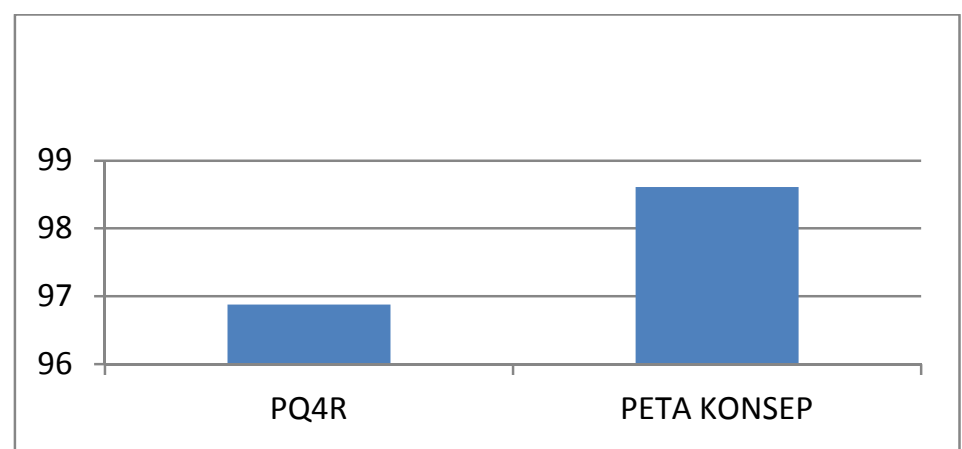

Gambar 1. Grafik Perbandingan Kinerja Guru pada Strategi Pembelajaran PQ4R dan Peta Konsep

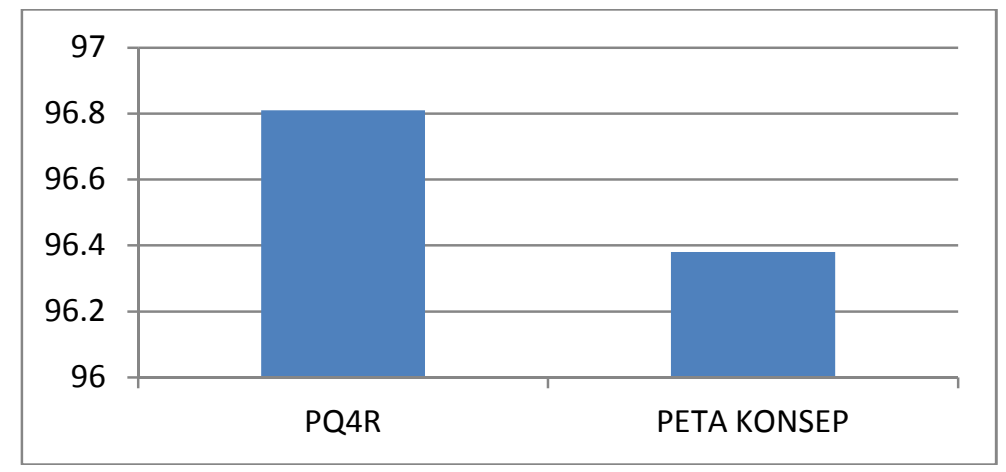

Gambar 2. Grafik Perbandingan aktivitas siswa pada Strategi Pembelajaran PQ4R dan Peta Konsep

Berdasarkan Gambar 1 tersebut, data rerata keterlaksanaan proses pembelajaran oleh guru model menunjukkan bahwa pada strategi pembelajaran peta konsep lebih berpotensi dalam meningkatkan kinerja guru dibandingkan dengan strategi pembelajaran PQ4R. Selanjutnya, Gambar 2 memberikan informasi bahwa aktivitas siswa lebih banyak dikembangkan pada strategi pembelajaran PQ4R dibandingkan strategi pembelajaran peta konsep. Kedua strategi yang digunakan tersebut telah dirancang dan dilaksanakan sesuai dengan karakteristik dari masingmasing strategi pembelajaran tersebut. Selanjutnya, berdasarkan hasil persentase data menunjukkan bahwa tahapan kedua strategi pembelajaran hampir mencapai $100 \%$ telah dilaksanakan oleh guru dan siswa selama proses pembelajaran berlangsung. Hal ini jika dianalisis lebih mendalam menunjukkan bahwa kedua strategi pembelajaran yang telah digunakan memiliki kecenderungan dalam meningkatkan kinerja guru dan aktivitas siswa selama proses pembelajaran.

Berdasarkan hasil temuan penelitian ini menunjukkan bahwa tahapan strategi pembelajaran peta konsep dan startegi pembelajaran PQ4Ryang telah dirancang mampu meningkatkan kinerja guru dan aktivitas siswa selama proses pembelajaran. Hal ini diduga karena karakteristik strategi pembelajaran PQ4R dan peta konsep yang tergambar pada setiap tahapan yang telah dirancang pada rencana pembelajaran berpotensi dalam meningkatkan kinerja guru dan siswa. Kedua strategi ini diyakini memiliki kemampuan dalam meningkatkan keterampilan berpikir dan keaktifan siswa selama proses pembelajaran. Selanjutnya, kedua strategi pembelajaran tersebut juga mampu membantu guru sebagai fasilitator dalam proses pembelajaran.

Hal tersebut sesuai dengan Munthe (2009) bahwa rancangan strategi pembelajaran merupakan cara seorang guru sebagai ujung tombak perubahan dalam melakukan usaha nyata untuk tercapainya kompetensi. Keberhasilan proses pembelajaran merupakan jaminan kualitas dan siswa telah memperoleh pengetahuan dan keterampilan sebagai bekal untuk memecahkan masalah dalam kehidupannya. Senada dengan hal tersebut Sanjaya (2012) menjelaskan bahwa peran guru dalam pembelajaran lebih ditekankan kepada bagaimana merancang berbagai sumber dan fasilitas yang tersedia untuk digunakan siswa 


\section{JEMS (Jurnal Edukasi Matematika dan Sains)}

Tersedia online di: http://e-journal.ikippgrimadiun.ac.id/index.php/JEMS

Volume 4, Nomor 2, September 2016, hal 129-132

dalam mempelajari sesuatu . Hal ini berarti usaha siswa mempelajari bahan pelajaran sebagai akibat perlakuan guru.

Selanjutnya terkait denga strategi pembelajaran PQ4R Slavin (2008) menjelaskan dengan mengikuti prosedur PQ4R, siswa terfokus pada pengorganisasian informasi yang bermakna dan melibatkan mereka dalam perumusan pertanyaan, penjabaran, dan kesempatan mengkaji kembali informasi. Penelitian Bibi \& Arif ( 2011) menemukan pengaruh strategi PQ4R secara holistik mengenai kemajuan pelajaran yang dicapai oleh siswa. Hal ini kemungkinan bahwa beberapa langkah strategi PQ4R dapat melebihi langkah-langkah strategi lainnya. Seperti halnya strategi pembelajaran PQ4R, peta konsep juga memberikan kontribusi yang sama dalam meningkatkan kualitas pembelajaran baik pada kinerja guru maupun aktivitas siswa. Menurut Ling dan Hong (2007) pembelajaran bermakna melalui peta konsep dimaksudkan untuk memasuki struktur kognitif pembelajar. Peta konsep telah digunakan untuk membantu siswa membangun dan mengatur basis pengetahuan pada suatu topik tertentu.. Senada dengan hal tersebut Novak (2008) menjelaskan bahwa peta konsep dikembangkan untuk mengikuti dan memahami perubahan pengetahuan siswa Selain itu, peta konsep merupakan perangkat yang sukses dalam membantu para pembelajar yang memiliki kemampuan rendah untuk dapat memperbaiki nilai-nilainya. Meskipun demikian, peta konsep dapat menjadi efektif untuk para pembelajar yang memiliki kemampuan yang tinggi apabila mereka terdorong untuk mengecheck peta konsep mereka secara berkala selama proses pembelajaran (Boujaoude \& May 2008).

\section{KESIMPULAN}

Berdasarkan hasil temuan tersebut
diperoleh informasi bahwa strategi
pembelajaran PQ4R mampu meningkatkan
aktivitas siswa selama proses pembelajaran.
Sedangkan strategi pembelajaran peta konsep
dapat meningkatkan kinerja guru dalam
proses pembelajaran. Namun demikian kedua
strategi pembelajaran ini memiliki potensi
yang sama untuk meningkatkan kinerja guru
dan aktivitas siswa selama proses pembelajaran Biologi siswa kelas XI IPA SMA di Banjarmasin.

\section{DAFTAR PUSTAKA}

Bibi, R. (2011). Effect of PQ4R Study Strategy in Scholostic Achievement of Secondary School Student in Punjab (Pakistan). Submitted In Partial Fulfillment of The Requirements For The Degree Of Doctor Of Philosophy In Education Foundation University Islamabad, Pakistan, (Online), (eprints.hec.gov.pk).

Boujaoude, S. \& May, A. (2008). The Effect of Using Concept Maps as Study Tools on Achievement in Chemistry. Eurasia Journal of Mathematics, Science and Technologi Education 4(3): 233-246. Beirut Lebanon: American University of Beirut, (Online), (www.ejmste.org).

Ling, Y. \& Hong, K.B. (2007). Concept Mapping and Pupils' Learning in Primary Science in Singapore. AsiaPacific Forum on Science Learning and Teaching, Volume 8, Issue 2, Article 11, (Online), (www.ied.edu.hk/apfslt/.../v8_issue2 .../lingy.pdf).

Munthe, B. (2009). Desain Pembelajaran. Yogyakarta: PT. Pustaka Insan Madani.

Novak, J. D. (2008). Concept Maps: What the heck is this ? Excerpted, Rearranged (and Annotated). Cornell University, (Online), (http://cmap.ihmc.us), .

Sagala, S. (2012). Konsep dan Makna Pembelajaran untuk Membantu Memecahkan Problematika Belajar dan Mengajar. Bandung: ALFABETA CV.

Sanjaya, W. (2012). Strategi Pembelajaran Berorientasi Standar Proses Pendidikan. Jakarta: Kencana Prenada Media Group.

Slavin. (2008). Psikologi Pendidikan teori dan Praktek. Jilid 1. Jakarta: Indeks.

Suyono \& Hariyanto. (2012). Belajar dan Pembelajaran Teori dan Konsep Dasar. Bandung: PT Remaja Rosdakarya. 